\title{
Selection of Suitable Potato Genotypes for Late-Sown Heat Stress Conditions Based on Field Performance and Stress Tolerance Indices
}

\author{
Abdullah Al Mahmud 1,*, M. Jahangir Alam ${ }^{1}$, Bimal Chandra Kundu ${ }^{2}$, Milan Skalicky ${ }^{3} \mathbb{D}$, M. Matiar Rahman $^{4}$, \\ E. H. M. Shofiur Rahaman ${ }^{5}$, Mousumi Sultana ${ }^{6}$, M. Samim Hossain Molla ${ }^{7}$, Akbar Hossain ${ }^{8, *(D) \text {, }}$ \\ Ahmed M. El-Shehawi ${ }^{9}$ (D), Marian Brestic ${ }^{3,10}{ }_{(\mathbb{D})}$ and Ayman EL Sabagh ${ }^{11, *(\mathbb{D})}$
}

check for updates

Citation: Al Mahmud, A.;

Alam, M.J.; Kundu, B.C.; Skalicky, M.; Rahman, M.M.; Rahaman, E.H.M.S.; Sultana, M.; Molla, M.S.H.; Hossain, A.; El-Shehawi, A.M.; et al. Selection of Suitable Potato Genotypes for Late-Sown Heat Stress Conditions Based on Field Performance and Stress Tolerance Indices. Sustainability 2021, 13, 2770. https://doi.org/ $10.3390 /$ su13052770

Received: 5 February 2021

Accepted: 26 February 2021

Published: 4 March 2021

Publisher's Note: MDPI stays neutral with regard to jurisdictional claims in published maps and institutional affiliations.

Copyright: (c) 2021 by the authors. Licensee MDPI, Basel, Switzerland. This article is an open access article distributed under the terms and conditions of the Creative Commons Attribution (CC BY) license (https:// creativecommons.org/licenses/by/ $4.0 /)$.
1 On-Farm Research Division (OFRD), Bangladesh Agricultural Research Institute (BARI), Gaibandha 5700, Bangladesh; jahangir.bari@gmail.com

2 Tuber Crops Research Centre, BARI, Gazipur 1701, Bangladesh; Kundubc@gmail.com

3 Department of Botany and Plant Physiology, Faculty of Agrobiology, Food, and Natural Resources, Czech University of Life Sciences Prague, Kamycka 129, 16500 Prague, Czech Republic; skalicky@af.czu.cz (M.S.); marian.brestic@uniag.sk (M.B.)

4 Regional Agricultural Research Station, BARI, Jashore 7400, Bangladesh; matiarbari@yahoo.com

5 International Potato Center (CIP), Dhaka, Banani, Dhaka 1213, Bangladesh; E.Rahaman@cgiar.org

6 Tuber Crops Research Sub-Centre, BARI, Bogura 5800, Bangladesh; mou0683@yahoo.com

OFRD, BARI, Rangpur 5400, Bangladesh; samimmolla@gmail.com

8 Bangladesh Wheat and Maize Research Institute, Dinajpur 5200, Bangladesh

9 Department of Biotechnology, College of Science, Taif University, P.O. Box 11099, Taif 21944, Saudi Arabia; a.elshehawi@tu.edu.sa

10 Department of Plant Physiology, Slovak University of Agriculture, Nitra, Tr. A. Hlinku 2, 94901 Nitra, Slovakia

11 Department of Agronomy, Faculty of Agriculture, Kafrelsheikh University, Kafrelsheikh 33516, Egypt

* Correspondence: mahmud.tcrc@gmail.com (A.A.M.); akbarhossainwrc@gmail.com (A.H.); ayman.elsabagh@agr.kfs.edu.eg (A.E.S.)

Abstract: International Potato Center (CIP), -bred potato genotypes produce various yields under heat stress conditions due to being sown late. To explore options for achieving this, a replicated experiment was conducted at the field of Tuber Crops Research Sub-Centre, Bangladesh Agricultural Research Institute, Bogura, Bangladesh to evaluate the performance of fourteen CIP-bred potato genotypes with two controls (Asterix and Granola). The experiment was laid out in a split-plot design with three replications. Several indices were applied to find out the suitable genotypes under heat stress. The plant height increased by $34.61 \%$ under heat stress, which was common in all the potato genotypes. Similarly, other yield-participating characters like stem per hill, canopy coverage (\%), plant vigor, and tuber number per plant were also increased under heat stress conditions. However, the tuber yield was decreased by $6.30 \%$ and $11.41 \%$, respectively when harvested at 70 and 90 days after plantation. Moreover, "CIP-203" yielded the highest $\left(40.66 \mathrm{t} \mathrm{ha}^{-1}\right)$ in non-stressed whereas, "CIP-118" yielded the highest (32.89 t/ha) in stressed conditions. Likewise, the bred "CIP-218" and "CIP-118" performed better under both growing conditions and yielded $>35.00 \mathrm{tha}{ }^{-1}$. According to a rank-sum test, among the fourteen potato genotypes, "CIP-218", "LB-7", "CIP-118", "CIP-232", and "CIP-112" were selected as heat-tolerant potatoes and can grow in both growing conditions with higher yield potential.

Keywords: heat tolerant; potato genotypes; tuber yield; stress indices

\section{Introduction}

Potato (Solanum tuberosum L.) is the world's leading vegetable crop that can safeguard the food security caused by its ever-increasing demand; it is the fourth-highest produced crop worldwide after wheat, corn and rice [1]. Being a highly nutritious food, potato is 
thought of as one of the most advantageous crops to lessen starvation, malnourishment, and poverty throughout the world, due to its high productivity, as shown by its remarkably high harvesting index above $75 \%$ [2,3]. So, it can play a notable role in human nutrition as an addition to other staple crops such as wheat and rice [4]. While the global potato production has expanded in the previous two decades, this was primarily due to an increase in the cultivated area, whereas the average yield rates persisted at a nearly steady rate in emerging countries [5]. Nearly all the annual world potato production is supplied by emerging countries, where it is cultivated in marginal regions susceptible to ecological inconsistencies such as heat, drought, and salinity [6].

According to Food and Agriculture Organization Corporate Statistical Database (FAOSTAT) [7], in Bangladesh, about 9.74 million tons (Mt) of potato were produced from about 0.47 million hectares (Mha) of land with an average yield of $20.41 \mathrm{t} \mathrm{ha}^{-1}$ and it ranks in 8 th position in production in the world and it ranks 2nd in the country [7]. Over two decades, total potato production of $9.47 \mathrm{Mt}$ has been reached from $1.55 \mathrm{Mt}$, in an area of of $0.47 \mathrm{Mha}$ from 0.136 Mha. During these periods per unit area, potato production has been increased 1.80 -fold [7]. The demand for potato production in the country is increasing in order to feed the ever-increasing population and by 2030 the country needs to increase yield from $20.43 \mathrm{t} \mathrm{ha}^{-1}$ to $41.50 \mathrm{t} \mathrm{ha}^{-1}$ of potatoes to attain food and nutrition security as well.

Potatoes can provide good yield even at day temperatures of $30-35^{\circ} \mathrm{C}$ provided nights are below $18{ }^{\circ} \mathrm{C}$. While night temperature reaches beyond $22^{\circ} \mathrm{C}$, there is little tuberization even when the day temperature is $25-27^{\circ} \mathrm{C}$. So, heat tolerance in potatoes is concerned more with the minimum night temperature than the maximum day temperature [8]. Temperatures higher than optimum considerably affect several physiological attributes related to yield and quality [9]. So, the features of heat tolerance which are important and need to be considered in the potato variety development system are the capability to tuberize at elevated night temperature and early maturity of the crop.

Expansion of potato production into the developing nations mostly occurs in tropical and subtropical areas, where the average temperatures are more elevated than the ideal temperature, which brings heat stress sensations into the minds of potato producers. Furthermore, to this expansion, global warming consequences add dangers for sustainable potato production in most regions [10]. Heat stress can adversely affect growth and yield in crop plants by altering several physiological processes and metabolic pathways [11]. According to Hijmans, [12], global warming alters the potato production in various regions of the world and the global potential yield of potato and is supposed to lead to a reduction of $18-32 \%$ without adaptation and of $9-18 \%$ with adaptation.

Breeding heat-tolerant potato genotypes/varieties which are now considered alongside the highest priorities in most breeding programs are used to ensure sustainable potato production under the above risks. The advance of heat-tolerant potato genotypes/clones that are able to tuberize under heat stress is a sensible and cost-effective way to lower the adverse effects of heat stress on the productivity of the crop. The problem of potato heat-susceptibility has gained more interest in the last few decades due to global climate change occurring. Under such situations, there is plenty of scope to find genotypes that have the innate capability of producing relatively higher yield under heat stress conditions. To develop heat stress-tolerant cultivars, efforts were initiated in the sub-continent [13-15] and the impacts of high temperatures on potato production will increase over the next decades, due to climate change and the extension of cultivation in heat prone areas [16-18].

Determination of morphological traits and yield impacting to the heat tolerance of potato genotypes is essential to improve the effectiveness of the procedure for the selection of tolerant varieties. This research is hypothesized with some morphological traits and yield that could be used to easily identify the heat-tolerant potato genotypes with high yield under late-sown (heat) field conditions. To experiment with the hypothesis, the responses of some attributes of potato genotypes to high-level temperatures were first evaluated under optimal or supra-optimal rising temperatures in a sub-tropical setting in Bangladesh. 


\section{Materials and Methods}

\subsection{Site Description}

The field experiment was conducted over two years (2015-2016 and 2016-2017) on the Experimental Farm of the Tuber Crops Research-Sub Centre (TCRSC) of Bangladesh Agricultural Research Institute (BARI) at Bogura $\left(24^{\circ} 51^{\prime \prime} \mathrm{N}, 89^{\circ} 18^{\prime \prime}\right.$ E and $17 \mathrm{~m}$ above sea level). The climate in this region is subtropical monsoon with an average annual rainfall of $1762 \mathrm{~mm}, 90 \%$ of which falls from May to September. Monthly average maximum temperature ranges from $25^{\circ} \mathrm{C}$ in January to $35.1^{\circ} \mathrm{C}$ in April, while monthly average minimum temperature ranges from $11.7^{\circ} \mathrm{C}$ in January to $25.6{ }^{\circ} \mathrm{C}$ in June. The soil of the experimental site belongs to Agroecological zone 25 (Level Barind Tract) developed over Madhupur clay. The predominant soils have shallow and deep grey terrace soils, silty, and puddled topsoil with plough pan. The soils are low in available moisture-holding capacity and slightly acidic to acidic ( $\mathrm{pH} 4.3$ to 6.1) in response. Organic matter status is very low and most of the available nutrients are low to medium [19]. During the trial period (November to March) monthly mean maximum and minimum temperature, and rainfall were recorded and are represented in Figure 1.
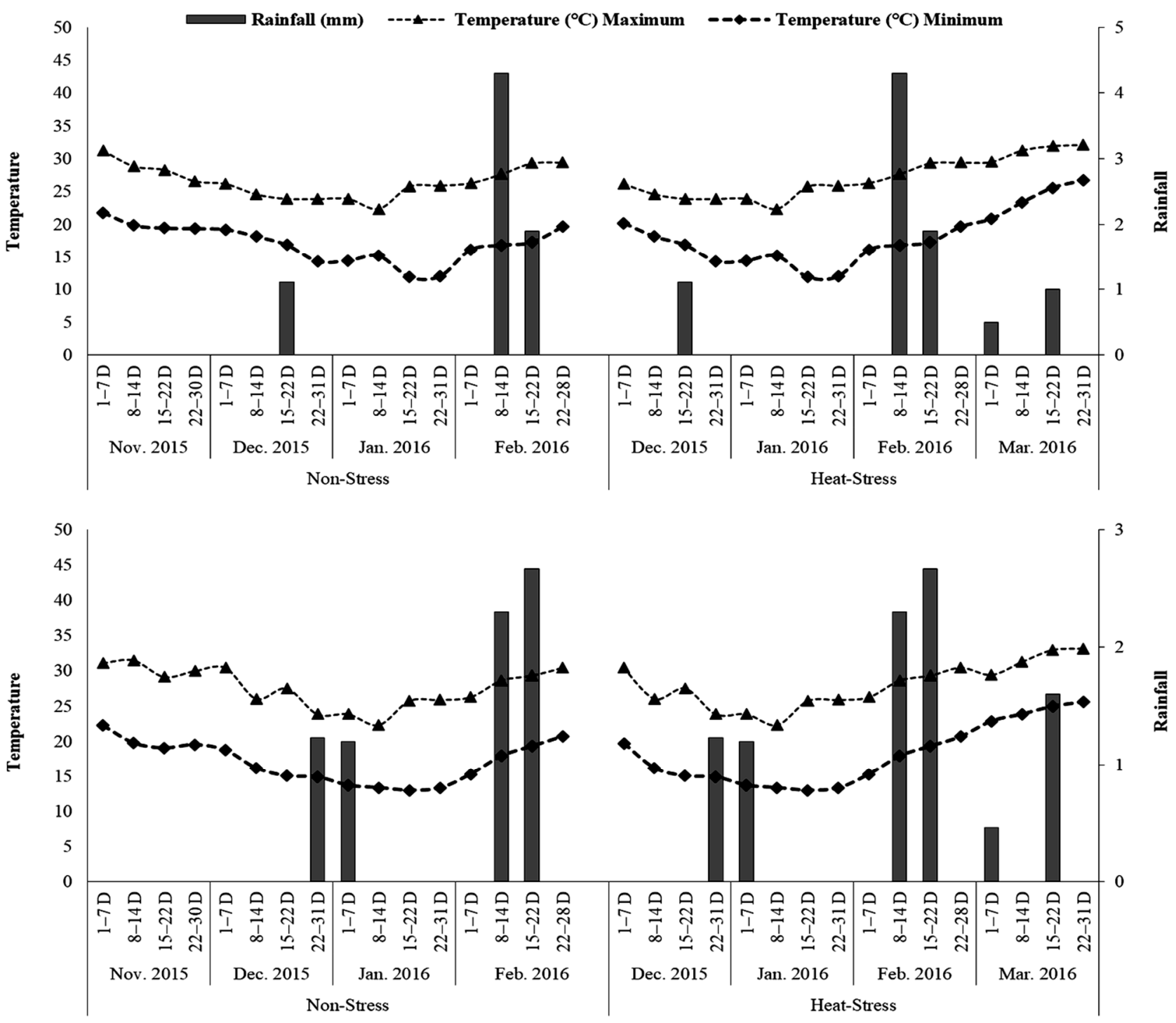

Figure 1. Maximum and minimum air temperature $\left({ }^{\circ} \mathrm{C}\right)$ and rainfall $(\mathrm{mm})$ in both years. 


\subsection{Plant Materials and Experimental Design}

Fourteen International Potato Centre (CIP)-bred potato clones of two popular varieties "Granola" and "Diamant" were used as control varieties in this trial. This experiment was designed in a split-plot design with randomized complete blocks (RCB) arrangements replicated thrice, considering the planting time (20 November and 20 December) in the main plots and potato genotypes in the subplots. Fourteen potato genotypes were selected for their known identity (tolerant to biotic and abiotic stress) (Table 1), yield potentiality and tuber characteristics (www.cipotato.org; accessed on 28 February 2021).

Table 1. List of the 16 potato genotypes with their characteristics used in screening for heat stress tolerance.

\begin{tabular}{|c|c|c|c|}
\hline S1. No. & Genotype/Variety & Tolerant Group & Tuber Characters \\
\hline 1 & $\begin{array}{l}\text { CIP-112 } \\
(380606.6)\end{array}$ & $\begin{array}{l}\text { Abiotic stress (Heat and } \\
\text { Salinity), Adapted for } \\
\text { Low-land Tropics }\end{array}$ & $\begin{array}{l}\text { Round tuber and medium-size tuber with } \\
\text { medium deep eyes, red skin with yellow flesh } \\
\text { color. }\end{array}$ \\
\hline 2 & $\begin{array}{l}\text { CIP-118 } \\
(388615.22)\end{array}$ & $\begin{array}{l}\text { Abiotic stress, Adapted for } \\
\text { Low-land Tropics }\end{array}$ & $\begin{array}{l}\text { White-cream skin with cream flesh color, } \\
\text { oblong-shaped with shallow eyes }\end{array}$ \\
\hline 3 & $\begin{array}{l}\text { CIP-127 } \\
(392820.1)\end{array}$ & $\begin{array}{l}\text { Abiotic stress (Heat), Adapted } \\
\text { for Low-land Tropics }\end{array}$ & $\begin{array}{l}\text { Oval-oblong shape and medium size tuber } \\
\text { with shallow eye depth. White cream skin with } \\
\text { cream flesh. }\end{array}$ \\
\hline 4 & $\begin{array}{l}\text { CIP-139 } \\
(396311.1)\end{array}$ & $\begin{array}{l}\text { Abiotic stress (Heat and } \\
\text { salinity), Adapted for } \\
\text { Low-land Tropics }\end{array}$ & $\begin{array}{l}\text { Short oval shape and medium to large size } \\
\text { tuber with slightly deep eye depth and red } \\
\text { skin color with pale yellow flesh color. }\end{array}$ \\
\hline 5 & $\begin{array}{l}\text { CIP-202 } \\
(302476.108)\end{array}$ & $\begin{array}{l}\text { Heat tolerant, High in Fe } \\
\text { content, Adapted for } \\
\text { Low-land Tropics }\end{array}$ & $\begin{array}{l}\text { Pink skin with yellow flesh, long-oblong shape } \\
\text { with the shallow eye. }\end{array}$ \\
\hline 6 & $\begin{array}{l}\text { CIP-203 } \\
(302498.70)\end{array}$ & $\begin{array}{l}\text { Heat tolerant, Adapted for } \\
\text { Low-land Tropics }\end{array}$ & $\begin{array}{l}\text { White-cream skin, cream flesh, oblong shape } \\
\text { with the shallow eye. }\end{array}$ \\
\hline 7 & $\begin{array}{l}\text { CIP-205 } \\
(302499.3)\end{array}$ & Salinity tolerant & $\begin{array}{l}\text { Cream skin color with cream flesh, oblong } \\
\text { shape, shallow eye. }\end{array}$ \\
\hline 8 & $\begin{array}{l}\text { CIP-218 } \\
(304351.109)\end{array}$ & Adapted for Low-land Tropics & $\begin{array}{l}\text { Red skin, cream flesh, round-oblong, shape, } \\
\text { slightly deep eye. }\end{array}$ \\
\hline 9 & $\begin{array}{l}\text { CIP-220 } \\
(304366.46)\end{array}$ & $\begin{array}{l}\text { Heat tolerant, Adapted for } \\
\text { Low-land Tropics }\end{array}$ & $\begin{array}{l}\text { Red skin, cream flesh, oblong shape and } \\
\text { slightly deep eye. }\end{array}$ \\
\hline 10 & $\begin{array}{l}\text { CIP-221 } \\
(304368.46)\end{array}$ & $\begin{array}{l}\text { Salinity tolerant, medium } \\
\text { resistant to late blight, } \\
\text { adapted for Low-land Tropics, }\end{array}$ & $\begin{array}{l}\text { White-cream skin, cream flesh, round shape, } \\
\text { shallow eye. }\end{array}$ \\
\hline 11 & $\begin{array}{l}\text { CIP-229 } \\
(304387.17)\end{array}$ & $\begin{array}{l}\text { Heat tolerant, Adapted for } \\
\text { Low-land Tropics }\end{array}$ & $\begin{array}{l}\text { White-cream skin, cream flesh, long-oblong } \\
\text { shape and shallow eye. }\end{array}$ \\
\hline 12 & $\begin{array}{l}\text { CIP-232 } \\
(304394.56)\end{array}$ & $\begin{array}{l}\text { Heat tolerant, Adapted for } \\
\text { Low-land Tropics }\end{array}$ & $\begin{array}{l}\text { White-cream skin, white flesh, Long-oblong } \\
\text { shape and shallow eye }\end{array}$ \\
\hline 13 & $\begin{array}{l}\text { CIP-235 } \\
(304405.47)\end{array}$ & $\begin{array}{l}\text { Heat tolerant, Adapted for } \\
\text { Low-land Tropics }\end{array}$ & $\begin{array}{l}\text { White-cream skin, cream flesh, round shape, } \\
\text { shallow eye }\end{array}$ \\
\hline 14 & $\begin{array}{l}\text { LB-7 } \\
(393371.58)\end{array}$ & Late Blight resistant & $\begin{array}{l}\text { White shin with white flesh, round shape and } \\
\text { medium-deep, pink eye. }\end{array}$ \\
\hline 15 & Granola & $\begin{array}{l}\text { Moderate yielding, popular } \\
\text { variety mostly suited for early } \\
\text { cultivation in Bangladesh }\end{array}$ & $\begin{array}{l}\text { Yellowish-white skin, white flesh, round shape } \\
\text { and shallow eye }\end{array}$ \\
\hline
\end{tabular}




\subsection{Crop Management}

Fourteen CIP-bred potato genotypes along with two control varieties were placed in the experiment at two different times (20 November and 20 December) to be able to create normal (control) and late (heat-stressed) situations. Potato seeds were sown on 20 November and 20 December each year, when soil moisture was optimum, at $1500 \mathrm{~kg}$ seed $\mathrm{ha}^{-1}$, with a row spacing of $60 \mathrm{~cm}$ and plant spacing of $25 \mathrm{~cm}$, maintaining a sowing depth of $3-5 \mathrm{~cm}$. Before planting, seed tubers of each genotype were treated with carbendazim $(0.1 \%)$ to control Rhizoctonia infection.

Total fertilizer application was $150 \mathrm{~kg} \mathrm{~N} \mathrm{ha}^{-1}$ of urea, $64 \mathrm{~kg} \mathrm{P} \mathrm{ha}^{-1}$ of triple superphosphate, $125 \mathrm{~kg} \mathrm{~K} \mathrm{ha}^{-1}$ of muriate of potash, $20 \mathrm{~kg} \mathrm{~S} \mathrm{ha}^{-1}$ of gypsum, $2 \mathrm{~kg} \mathrm{Zn} \mathrm{ha}^{-1}$ of zinc sulphate and $1.5 \mathrm{~kg} \mathrm{~B} \mathrm{ha}^{-1}$ of boric acid. Half of the $\mathrm{N}$ and all the $\mathrm{P}, \mathrm{K}, \mathrm{S}, \mathrm{Zn}$ and $\mathrm{B}$ fertilizers were broadcasted just before plantation, and the rest of the $\mathrm{N}$ was top dressed at 30-35 days after plantation (DAP) as well as the earthing up also being done at the same time. The crops were irrigated four times in both years for the normal and heat stress treatment, respectively. Light irrigation was applied at 8-10 DAP for proper emergence of the tubers and considered as the 1st irrigation; the 2nd and 3rd irrigations were applied at 30-35 and 45-50 DAP maintaining 2/3rd depth of the furrow. Finally, at 60-65 days (d), light irrigation was also applied. Two hand weeding was done before the 2nd (at 30-35 DAP) and 3rd (60-65 DAP) irrigations by spading in between the ridges and covering the ridges with loose soil.

During land preparation, carbofuran (Furadan $5 \mathrm{G}^{\circledR}$, Padma Oil Company Limited, 7-9 Karwan Bazar, BTMC Bhaban (10th Floor), Dhaka 1215, Bangladesh) @ 500 g a.i. ha ${ }^{-1}$ as basal during land preparation was applied to control Cutworm infestation and Imidacloprid (Admire 20 SL ${ }^{\circledR}$, Bayer Crop Science Limited, Dhaka 1215, Bangladesh) @ $25 \mathrm{~g}$ a.i. ha ${ }^{-1}$ was sprayed in two instalments at 45 and $60 \mathrm{DAP}$ to control Aphid infestation. The crops were also sprayed alternatively with Mancozeb (Dithane-M $45^{\circledR}$, Bayer Crop Science Limited, Dhaka 1215, Bangladesh) @ $1.76 \mathrm{~kg}$ a.i. ha ${ }^{-1}$ and Mancozeb @ $98.8 \mathrm{~g}$ a.i. ha ${ }^{-1}$ and Fenamidin @ 494 g a.i. ha ${ }^{-1}$ (Secure ${ }^{\circledR}$, Bayer Crop Science Limited, Dhaka 1215, Bangladesh) at $15 \mathrm{~d}$ interval to prevent the Late Blight infection of potatoes. The crop was harvested at 70 and 90 DAP to observe the earliness and regular bulking of the tubers. Data were recorded on various morphological and yield participating characters. Tuber yield was recoded from a $4 \mathrm{~m}^{2}(2 \mathrm{~m} \times 2 \mathrm{~m})$ area and converted to $\mathrm{tha}^{-1}$. Plant height $(\mathrm{cm})$, no. of stem plants ${ }^{-1}$, canopy coverage (\%) and plant vigor were recorded from the average of 10 plants at 60 DAP. Days to tuber initiation were recorded when $50 \%$ of the tubers formed into the plants from an average of 10 plants in each of the plots. Similarly, no. of tuber plants $^{-1}$ was also recorded from the average of 10 plants. Finally, after harvest, the potatoes were graded (good or bad quality), and the good ones considered as marketable yield (more than $20 \mathrm{~g}$ ) and the poor-quality ones as non-marketable (less than $20 \mathrm{~g}$, deformed and abnormal tubers) yield and expressed in $\mathrm{tha}^{-1}$.

\subsection{Calculation of Stress Tolerance Indices}

Stress tolerance indices: yield stability index (YSI), heat susceptibility index (HSI), yield reduction ratio (YRR), mean productivity (MP), geometric mean productivity (GMP), tolerance index (TOL), heat tolerance index (HTI), stress resistance index (SRI), abiotic tolerance index (ATI), yield index (YI) and relative stress index (RSI) were calculated based on tuber yield under heat stress (Ys) and non-stress (Yp) conditions. Drought tolerance indices were calculated by using the equations cited in Table 2. In the above formulas, Ys and $Y p$ are the mean yield of genotypes under stress and non-stress conditions, respectively. For the ranking method for screening stress-tolerant genotypes, a rank-sum (RS) [20] was calculated by the following relationship: Rank sum (RS) = Rank mean + Standard deviation of rank (SDR). 
Table 2. The following stress, tolerance indices were calculated for selecting heat-tolerant potatoes.

\begin{tabular}{|c|c|c|}
\hline Index Name & Outcome & Reference \\
\hline Yield stability index (YSI) & $\begin{array}{l}\text { The genotypes with high YSI values can be } \\
\text { regarded as stable genotypes under stress and } \\
\text { non-stress conditions. }\end{array}$ & Bouslama and Schapaugh, [21] \\
\hline Heat susceptibility index (HSI) & $\begin{array}{l}\text { The genotypes with HSI }<1 \text { are more resistant to } \\
\text { stress conditions }\end{array}$ & Fisher and Maurer, [22] \\
\hline Yield reduction ratio (YRR) & $\begin{array}{l}\text { The genotypes with a low value of this index will } \\
\text { be suitable for stress conditions }\end{array}$ & Golestani-Araghi and Asad, [23] \\
\hline Mean productivity (MP) & $\begin{array}{l}\text { The genotypes with a high value of this index will } \\
\text { be more advantageous }\end{array}$ & Rosielle and Hamblin, [24] \\
\hline Geometric mean productivity (GMP) & $\begin{array}{l}\text { The genotypes with the high value of this index } \\
\text { will be more desirable }\end{array}$ & Kristin et al. [25] \\
\hline Tolerance (TOL) & $\begin{array}{l}\text { The genotypes with low values of this index are } \\
\text { more consistent in two different conditions. }\end{array}$ & Rosielle and Hamblin, [24] \\
\hline Hear tolerance index (HTI) & $\begin{array}{l}\text { The genotypes with high HTI values will be } \\
\text { tolerant to stress }\end{array}$ & Fernandez, [26] \\
\hline Stress resistance index (SRI) & $\begin{array}{l}\text { The genotypes with a high value of this index will } \\
\text { be suited to stress conditions }\end{array}$ & Lan, [27] \\
\hline Abiotic stress tolerance index (ASTI) & $\begin{array}{l}\text { The genotypes with a low value of this index is } \\
\text { appropriate for the stress conditions }\end{array}$ & Moovasi et al. [28] \\
\hline Yield index (YI) & $\begin{array}{l}\text { The genotypes with a high value of this index will } \\
\text { be appropriate for stress conditions }\end{array}$ & Gavuzzi et al. [29] \\
\hline Relative stress index (RSI) & $\begin{array}{l}\text { The genotypes with a high value of this index will } \\
\text { be appropriate for the stress conditions }\end{array}$ & Fisher and Maurer, [22] \\
\hline Rank sum (RS) & $\begin{array}{l}\text { The genotypes with a low value of this index will } \\
\text { be suitable for stress conditions }\end{array}$ & Farshadfar and Elyasi, [20] \\
\hline
\end{tabular}

\subsection{Statistical Analysis}

Data were analyzed by ANOVA (using STAR) to evaluate differences between treatments, and the means were separated using the least significant difference (LSD) at the 5\% level of significance. Two years' (2015-2016 and 2016-2017 crop years) average data on different morphological and yield attributes were subjected to the proper statistical analysis of variance (ANOVA) of split-plot design using the "STAR" software package. Tukey's Honest Significant Difference (HSD) test was applied to detect statistical variations among genotypes, planting times and interaction treatment means when the F-test for these treatments was significant at $5 \%$ probability level.

\section{Results and Discussion}

\subsection{Environmental Conditions}

Average monthly air temperature during the regular growing period differed between 13.41 and $28.75{ }^{\circ} \mathrm{C}$ in $2015-2016$ and between 13.31 and $30.43^{\circ} \mathrm{C}$ in 2016-2017 (Figure 1). However, it ranged from 13.41 to $31.24{ }^{\circ} \mathrm{C}$ during the late growing period in 2015-2016 and from 13.31 to $31.72{ }^{\circ} \mathrm{C}$ in $2016-2017$. From plant rise to harvest, the average maximum air temperature was $26.50^{\circ} \mathrm{C}$ and $27.63^{\circ} \mathrm{C}$ under regular growing conditions in 2015-2016 and 2016-2017, separately (Figure 1). Under late growing conditions, the average maximum air temperature from emergence to harvest was $27.12{ }^{\circ} \mathrm{C}$ and $27.92{ }^{\circ} \mathrm{C}$ in $2015-2016$ and 2016-2017, respectively (Figure 1).

The average maximum air temperatures from the tuber development to harvest in both years under regular and late growing environments in both years were less than $30.0^{\circ} \mathrm{C}$. The average minimum air temperatures from emergence to harvest, under regular growing 
conditions, were $17.04{ }^{\circ} \mathrm{C}$ and $16.98^{\circ} \mathrm{C}$ in 2015-2016 and 2016-2017, separately (Figure 1). Under late growing conditions, the average maximum air temperatures from emergence to harvest were $18.10^{\circ} \mathrm{C}$ and $18.08^{\circ} \mathrm{C}$ in 2015-2016 and 2016-2017, respectively (Figure 1). The average maximum air temperatures from tuberization to harvest in both years under regular and late growing conditions in both years were nearer to $18.0^{\circ} \mathrm{C}$, respectively.

However, from the graphs in both years, it was clear that minimum air temperatures started rising in fourth and third weeks of February (more than $18^{\circ} \mathrm{C}$ ) and at harvest reached at $25.57{ }^{\circ} \mathrm{C}$ and $24.96{ }^{\circ} \mathrm{C}$, respectively. So, we can say that in the late growing seasons potato genotypes faced slight heat stress during the tuber bulking to tuber maturity stages, which limited the tuber yield in different degrees.

\subsection{Morphological Attributes}

In terms of the genotype $\times$ environment interaction, aboveground vegetative growth attributes such as plant height, stem per plant and canopy coverage were markedly influenced by elevated temperatures (Table 3). The plant height of potato genotypes was enhanced in elevated-temperature situations with an overall average increment of $(34.61 \%)$ under heat stress conditions compared to non-stress conditions observed commonly in all the genotypes. Plant height among the genotypes was ranged from 32.80 to $69.00 \mathrm{~cm}$ (mean: $51.54 \pm 8.73$ ) in non-stress planted plants, while it was 45.46 to $93.60 \mathrm{~cm}$ (mean: $69.38 \pm 12.41$ ) in heat-stressed plants (Table 3). "CIP-218" produced the maximum plant height in both conditions with $35.65 \%$ extra growth. Under the non-stress situation, "CIP232" produced the smallest plant; however, "Granola" produced the smallest plant in the heat stress situation.

Table 3. Plant height and stem plants ${ }^{-1}$ at 60 days after plantation (DAP) of 16 potato genotypes under non-stress and heat stress conditions.

\begin{tabular}{|c|c|c|c|c|c|c|}
\hline \multirow{2}{*}{ Clones/Varieties } & \multicolumn{2}{|c|}{ Average Plant Height at 60 DAP } & \multirow{2}{*}{$\begin{array}{l}\% \text { Change over } \\
\text { Non-Stress (+l-) }\end{array}$} & \multicolumn{2}{|c|}{ Average Stems per Plant at $60 \mathrm{DAP}$} & \multirow{2}{*}{$\begin{array}{l}\% \text { Change over } \\
\text { Non-Stress }(+l-)\end{array}$} \\
\hline & Non-Stress & Heat Stress & & Non-Stress & Heat Stress & \\
\hline CIP-112 & $50.13 \mathrm{bcd}$ & $57.26 \mathrm{de}$ & 14.22 & $6.27 \mathrm{ab}$ & $9.07 \mathrm{ab}$ & 44.66 \\
\hline CIP-118 & $53.46 \mathrm{abc}$ & $64.13 \mathrm{~cd}$ & 19.96 & $4.40 \mathrm{abc}$ & $7.20 \mathrm{abcd}$ & 63.64 \\
\hline CIP-127 & $47.40 \mathrm{bcd}$ & $57.13 \mathrm{de}$ & 20.53 & $3.60 \mathrm{bc}$ & $4.47 \mathrm{~d}$ & 24.17 \\
\hline CIP-139 & $50.26 \mathrm{bcd}$ & $74.00 \mathrm{bcd}$ & 47.23 & $2.80 \mathrm{c}$ & $5.33 \mathrm{~cd}$ & 90.36 \\
\hline CIP-202 & $57.26 \mathrm{ab}$ & $80.93 \mathrm{abc}$ & 41.34 & $5.73 \mathrm{abc}$ & $7.27 \mathrm{abcd}$ & 26.88 \\
\hline CIP-203 & $56.00 \mathrm{abc}$ & $65.66 \mathrm{~cd}$ & 17.25 & $5.47 \mathrm{abc}$ & $7.47 \mathrm{abcd}$ & 36.56 \\
\hline CIP-205 & $59.26 \mathrm{ab}$ & $73.13 \mathrm{bcd}$ & 23.41 & $3.33 \mathrm{bc}$ & $5.47 \mathrm{~cd}$ & 64.26 \\
\hline CIP-218 & $69.00 \mathrm{a}$ & $93.60 \mathrm{a}$ & 35.65 & $6.93 \mathrm{a}$ & $9.93 \mathrm{a}$ & 43.29 \\
\hline CIP-220 & $49.26 \mathrm{bcd}$ & $70.33 \mathrm{~cd}$ & 42.77 & $6.87 \mathrm{a}$ & $8.73 \mathrm{ab}$ & 27.07 \\
\hline CIP-221 & $45.53 \mathrm{bcd}$ & $72.40 \mathrm{bcd}$ & 59.02 & $4.27 \mathrm{abc}$ & $6.6 \mathrm{bcd}$ & 54.57 \\
\hline CIP-229 & $48.13 \mathrm{bcd}$ & 63.33 cde & 31.58 & $6.33 \mathrm{ab}$ & $7.40 \mathrm{abcd}$ & 16.90 \\
\hline CIP-232 & $32.80 \mathrm{~d}$ & $59.73 \mathrm{de}$ & 82.10 & $4.40 \mathrm{abc}$ & $4.93 \mathrm{~cd}$ & 12.05 \\
\hline CIP-235 & $54.86 \mathrm{abc}$ & $75.00 \mathrm{abcd}$ & 36.71 & $3.60 \mathrm{bc}$ & $6.07 \mathrm{bcd}$ & 68.61 \\
\hline Granola & $38.33 \mathrm{~cd}$ & $45.46 \mathrm{e}$ & 18.60 & $5.60 \mathrm{abc}$ & $6.00 \mathrm{bcd}$ & 7.14 \\
\hline LB-7 & $62.13 \mathrm{ab}$ & $91.00 \mathrm{ab}$ & 46.47 & $7.07 \mathrm{a}$ & $7.47 \mathrm{abcd}$ & 5.66 \\
\hline Asterix & 50.80 abcd & $66.93 \mathrm{~cd}$ & 31.75 & $7.47 \mathrm{a}$ & $7.47 \mathrm{abcd}$ & 2.75 \\
\hline Range & $32.80-69.00$ & $45.46-93.60$ & & $2.80-7.47$ & $4.47-9.93$ & \\
\hline Mean \pm SD & $51.54 \pm 8.73$ & $69.38 \pm 12.41$ & & $5.25 \pm 1.48$ & $6.93 \pm 1.52$ & \\
\hline
\end{tabular}

Means with the same letter are not significantly different.

Our results are consistent with an increase in net foliar photosynthesis of "Desirée" plants under relatively mild heat stress (30-20 ${ }^{\circ} \mathrm{C}$, day-night) [30], even though the reported chlorophyll content decreased in this cultivar. The increased plant height under heatstress conditions in our study may also be due to higher shoot-to-tuber allocation of photosynthates. Our results of increased height growth under heat stress are in agreement with previous studies [31].

All potato genotypes reacted with an average increase in stem number per plant of about $32 \%$ in elevated temperature/heat stress conditions (Table 3 ). The variation in stem number per plant among genotypes ranged from 2.80 to 7.47 in non-stress planted plants, and 4.47 to 9.93 in heat-stressed plants with corresponding means of $5.25 \pm 1.48$ and $6.93 \pm 1.52$, respectively (Table 3 ). In non-stress planting, the highest stem number per plant was found in "Asterix" and the lowest was in "CIP-139". In heat stress, the highest 
stem number per plant was found in "CIP-218" and the lowest was found in "CIP-127". Under heat stress conditions, the genotype "CIP-139" exhibited with the highest change $(90.36 \%)$ in stem number per plant while "Asterix" was the lowest (2.75\%) in non-stress conditions (Table 3).

However, in comparison of non-stress and heat stress plantations, more average plant canopy was covered by the genotypes noted in heat stress conditions. Canopy coverage of non-stress planted plants was ranged from $78.33 \%$ to $98.33 \%$ with an average of $86.77 \%$ and that of late-planted plants from $81.67 \%$ to $98.33 \%$ with a mean of $90.83 \%$ (Table 4 ). In non-stress conditions, more than $90 \%$ of the plant canopy was covered by seven genotypes, whereas, in heat stress, it was covered by eleven genotypes. "CIP-203" and the control "Granola" covered the mean highest and lowest canopy at 60 DAP.

Table 4. Canopy coverage (\%) and plant vigor of 16 potato genotypes under non-stress and heat stress conditions.

\begin{tabular}{|c|c|c|c|c|c|c|}
\hline \multirow{2}{*}{ Clones/Varieties } & \multicolumn{2}{|c|}{ Canopy Coverage at 60 DAP } & \multirow{2}{*}{$\begin{array}{l}\% \text { Change over } \\
\text { Non-Stress (+/-) }\end{array}$} & \multicolumn{2}{|c|}{ Plant Vigor at 60 DAP } & \multirow{2}{*}{$\begin{array}{l}\% \text { Change over } \\
\text { Non-Stress }(+/-)\end{array}$} \\
\hline & Non-Stress & Heat Stress & & Non-Stress & Heat Stress & \\
\hline CIP-112 & 85.00 cde & 90.00 bcde & 5.88 & $4.00 \mathrm{~b}$ & $4.33 \mathrm{ab}$ & 8.25 \\
\hline CIP-118 & 83.33 cde & 85.00 def & 2.00 & $4.00 \mathrm{~b}$ & $5.00 \mathrm{a}$ & 25.00 \\
\hline CIP-127 & $90.00 \mathrm{bc}$ & $95.00 \mathrm{ab}$ & 5.56 & $4.00 \mathrm{~b}$ & $4.00 \mathrm{bc}$ & 0.00 \\
\hline CIP-139 & $91.67 \mathrm{ab}$ & $93.33 \mathrm{abc}$ & 1.81 & $5.00 \mathrm{a}$ & $5.00 \mathrm{a}$ & 0.00 \\
\hline CIP-202 & $93.33 \mathrm{ab}$ & $93.33 \mathrm{abc}$ & 0.00 & $5.00 \mathrm{a}$ & $5.00 \mathrm{a}$ & 0.00 \\
\hline CIP-203 & $98.33 \mathrm{a}$ & $98.33 \mathrm{a}$ & 0.00 & $5.00 \mathrm{a}$ & $4.00 \mathrm{bc}$ & -20.00 \\
\hline CIP-205 & $88.33 \mathrm{bcd}$ & $95.00 \mathrm{ab}$ & 7.55 & $4.00 \mathrm{~b}$ & $4.33 \mathrm{ab}$ & 8.25 \\
\hline CIP-218 & $90.00 \mathrm{bc}$ & $91.67 \mathrm{abcd}$ & 1.86 & $5.00 \mathrm{a}$ & $4.33 \mathrm{ab}$ & -13.40 \\
\hline CIP-220 & 86.67 cde & 90.00 bcde & 3.84 & $4.00 \mathrm{~b}$ & $4.33 \mathrm{ab}$ & 8.25 \\
\hline CIP-221 & $80.00 \mathrm{e}$ & 88.33 bcdef & 10.41 & $4.00 \mathrm{~b}$ & $4.33 \mathrm{ab}$ & 8.25 \\
\hline CIP-229 & $80.00 \mathrm{e}$ & 85.00 def & 6.25 & $4.00 \mathrm{~b}$ & $4.33 \mathrm{ab}$ & 8.25 \\
\hline CIP-232 & 85.00 cde & $98.33 \mathrm{a}$ & 15.68 & $4.00 \mathrm{~b}$ & $4.00 \mathrm{bc}$ & 0.00 \\
\hline CIP-235 & $81.67 \mathrm{de}$ & $95.00 \mathrm{ab}$ & 16.32 & $4.00 \mathrm{~b}$ & $4.67 \mathrm{ab}$ & 16.75 \\
\hline Granola & $78.33 \mathrm{e}$ & $81.67 \mathrm{f}$ & 4.26 & $3.00 \mathrm{c}$ & $3.33 c$ & 11.00 \\
\hline LB-7 & $93.33 \mathrm{ab}$ & $95.00 \mathrm{ab}$ & 1.79 & $5.00 \mathrm{a}$ & $5.00 \mathrm{a}$ & 0.00 \\
\hline Asterix & $83.33 \mathrm{c}-\mathrm{e}$ & 83.33 ef & 0.00 & $4.00 \mathrm{~b}$ & $4.67 \mathrm{ab}$ & 16.75 \\
\hline Range & $78.33-98.33$ & $81.67-98.33$ & & $3.00-5.00$ & $3.33-5.00$ & \\
\hline Mean \pm SD & $86.77 \pm 5.69$ & $91.15 \pm 5.22$ & & $4.25 \pm 0.58$ & $4.42 \pm 0.46$ & \\
\hline
\end{tabular}

Means with the same letter are not significantly different.

Plant vigor of non-stress planted plants varied from 3.00 to 5.00 with an average of 4.25 and that of heat stress planted plants from 3.33 to 5.00 with a mean of 4.42 (Table 4). In non-stress clones, the most vigorous plant growth was found in five clones ("CIP-139", "CIP-202", "CIP-203", "CIP-218" and "LB-7") while in the heat-stressed clones it was three ("CIP-118", "CIP-202" and "LB-7"). The mean highest plant vigor was found in "CIP-202". However, in comparison of non-stress and stress plantation, more vigorous plants on average were found in late-planted genotypes.

\subsection{Yield Attributes}

The genotypes, growing conditions, and their interactions were significantly effective on all agricultural traits such as days to tuber initiation, tuber number at $90 \mathrm{DAP}$, tuber yield at 90 DAP and are shown in Table 5. In non-stress planted plants, days to tuber initiation ranged from 25.00 to $32.33 \mathrm{~d}$ with an average of $30.15 \mathrm{~d}$ and that of stress planted plants from 26.67 to 32.67 with a mean of $30.19 \mathrm{~d}$ (Table 4). In non-stress planting, "CIP-218" took the minimum and "CIP-112" took the maximum days to tuberization; however, in stress planting, "CIP-202" took the maximum and "CIP-218" took the minimum days to tuberization. In both conditions, minimum days were required for tuberization in "CIP-218". "CIP-112" took the average maximum days to tuberization. 
Table 5. Average days to tuber initiation and tuber number plant ${ }^{-1}$ at $90 \mathrm{DAP}$ of 16 potato genotypes under non-stress and heat stress conditions.

\begin{tabular}{|c|c|c|c|c|c|c|}
\hline \multirow{2}{*}{ Clones/Varieties } & \multicolumn{2}{|c|}{ Days to Tuber Initiation } & \multirow{2}{*}{$\begin{array}{l}\% \text { Change over } \\
\text { Non-Stress (+/-) }\end{array}$} & \multicolumn{2}{|c|}{ Tuber Number per Plant at 90 DAP } & \multirow{2}{*}{$\begin{array}{l}\% \text { Change over } \\
\text { Non-Stress }(+/-)\end{array}$} \\
\hline & Non-Stress & Heat Stress & & Non-Stress & Heat Stress & \\
\hline CIP-112 & $32.33 \mathrm{a}$ & $32.00 \mathrm{a}$ & -1.02 & $16.40 \mathrm{a}$ & $10.15 \mathrm{abc}$ & -38.11 \\
\hline CIP-118 & $30.00 \mathrm{ab}$ & $29.00 \mathrm{abc}$ & -3.33 & $11.26 \mathrm{bc}$ & $6.97 \mathrm{bc}$ & -38.10 \\
\hline CIP-127 & $31.00 \mathrm{ab}$ & $30.00 \mathrm{abc}$ & -3.23 & $10.26 \mathrm{bc}$ & $7.81 \mathrm{bc}$ & -23.88 \\
\hline CIP-139 & $32.33 \mathrm{a}$ & $31.67 \mathrm{a}$ & -2.04 & $6.06 \mathrm{c}$ & $8.38 \mathrm{bc}$ & 38.28 \\
\hline CIP-202 & $32.00 \mathrm{ab}$ & $30.33 \mathrm{abc}$ & -7.16 & $9.50 \mathrm{bc}$ & $8.53 \mathrm{bc}$ & -10.21 \\
\hline CIP-203 & $32.00 \mathrm{ab}$ & $31.00 \mathrm{abc}$ & -3.13 & $13.43 \mathrm{ab}$ & $11.75 \mathrm{ab}$ & -12.51 \\
\hline CIP-205 & $31.33 \mathrm{ab}$ & $28.67 \mathrm{bc}$ & -8.49 & $12.87 \mathrm{abc}$ & $9.86 \mathrm{abc}$ & -23.39 \\
\hline CIP-218 & $26.67 \mathrm{c}$ & $25.00 \mathrm{c}$ & -6.26 & $13.74 \mathrm{ab}$ & $10.00 \mathrm{abc}$ & -27.22 \\
\hline 'CIP-220' & $31.33 \mathrm{ab}$ & $29.00 \mathrm{abc}$ & -7.44 & $11.14 \mathrm{bc}$ & $11.14 \mathrm{ab}$ & 0 \\
\hline CIP-221 & $31.33 \mathrm{ab}$ & $27.67 \mathrm{bc}$ & -11.68 & $14.14 \mathrm{ab}$ & $9.20 \mathrm{abc}$ & -34.94 \\
\hline CIP-229 & $31.33 \mathrm{ab}$ & $27.00 \mathrm{bc}$ & -13.82 & $13.57 \mathrm{ab}$ & $13.95 \mathrm{a}$ & -2.86 \\
\hline CIP-232 & $31.67 \mathrm{ab}$ & $31.00 \mathrm{ab}$ & -2.12 & $9.92 \mathrm{bc}$ & $7.47 \mathrm{bc}$ & -24.70 \\
\hline CIP-235 & $32.00 \mathrm{ab}$ & $29.67 \mathrm{abc}$ & -7.28 & $12.45 \mathrm{abc}$ & $5.77 \mathrm{c}$ & -53.65 \\
\hline Granola & $30.00 \mathrm{ab}$ & 29.33 abc & -2.23 & $10.76 \mathrm{bc}$ & $9.34 \mathrm{abc}$ & -13.20 \\
\hline LB-7 & $27.67 \mathrm{bc}$ & $27.00 \mathrm{bc}$ & -2.42 & $11.32 \mathrm{bc}$ & $11.44 \mathrm{ab}$ & 1.06 \\
\hline Asterix & $30.00 \mathrm{ab}$ & $28.00 \mathrm{bc}$ & -6.67 & $10.79 \mathrm{bc}$ & $9.10 \mathrm{abc}$ & -15.66 \\
\hline Range & $26.67-32.67$ & $25.00-32.00$ & & $6.06-13.97$ & 5.77-13.57 & \\
\hline Mean \pm SD & $30.85 \pm 1.67$ & $29.15 \pm 1.90$ & & $11.75 \pm 2.40$ & $9.40 \pm 1.97$ & \\
\hline
\end{tabular}

Means with the same letter are not significantly different.

High temperatures resulted in considerable reductions in tuber number in all genotypes except for "CIP-139" and "LB-7" (Table 5). The variation in tuber number per plant among the genotypes varied from 5.77 to 13.77 in stress plants, and 6.06 to 13.97 in nonstressed plants with corresponding means of 9.40 and 11.75, respectively (Table 5). In stress planting conditions, an average of $20.00 \%$ reduced tuber number per plant was recorded compared to non-stress conditions. Except for "CIP-139" and "LB-7", all the genotypes produced a higher number of tubers per plant in the stress planting condition. In both conditions, "CIP-220" produced the same tuber number per plant. "CIP-112" produced the average maximum tuber number per plant under non-stress conditions while and CIP-239 produced the average minimum tuber number per plant under stress conditions.

Consequently, the total tuber yield of genotypes was also noticeably decreased at 70 and $90 \mathrm{~d}$ up to harvest due to heat stress during the growing season. Adjusted yield $\left(\mathrm{t} \mathrm{ha}^{-1}\right)$ at $70 \mathrm{~d}$ of sixteen potato genotypes varied significantly under both non-stress and stress planted situations (Table 6). It was found that the stress planting condition reduced mean yield $6.30 \%$ at $70 \mathrm{~d}$ harvest. Genotype "CIP-118" exhibited the highest yield (34.17 and $30.27 \mathrm{t} \mathrm{ha}^{-1}$ ) in non-stress and stress planting conditions and showed a reduction of $11.41 \%$. On the other hand, "LB-7" yielded the lowest $\left(20.92 \mathrm{t} \mathrm{ha}^{-1}\right)$ in the non-stress condition and with the minimum yield reduction $(2.29 \%)$. The lowest yield in the stress planting condition was found in "CIP-205" (18.83 tha $\left.{ }^{-1}\right)$ with $10.93 \%$ yield reduction. The maximum yield reduction (26.32\%) was found in "CIP-229" at $70 \mathrm{~d}$ harvest. From the results, it was found that more than $30 \mathrm{t} \mathrm{ha}^{-1}$ yield was harvested from "CIP-118" and "CIP-218" at both conditions with a reduction of $11.41 \%$ and $7.45 \%$, respectively.

Regarding adjusted tuber yield $\left(\mathrm{t} \mathrm{ha}^{-1}\right)$ at $90 \mathrm{DAP}$, the variation among the genotypes ranged from 25.32 to $40.66 \mathrm{tha}^{-1}$ in non-stress, and 20.39 to $32.89 \mathrm{t} \mathrm{ha}^{-1}$ in stress planted conditions with corresponding means of 32.78 and $25.80 \mathrm{t} \mathrm{ha}^{-1}$, respectively (Table 7). "CIP-118" exhibited the highest yield ( 34.17 and $\left.30.27 \mathrm{t} \mathrm{ha}^{-1}\right)$ in non-stress and stress planting and showed a reduction of $11.41 \%$, whereas "LB-7" yielded the lowest $\left(20.92 \mathrm{tha}^{-1}\right)$ in non-stress conditions and with the minimum yield reduction $(2.29 \%)$. The lowest yield in stress planting was found in "CIP-205" (18.83 $\mathrm{t} \mathrm{ha}^{-1}$ ) with $10.93 \%$ yield reduction. The maximum yield reduction (26.32\%) was found in "CIP-229" at $70 \mathrm{~d}$ harvest. From the results, it was found that more than $30 \mathrm{t} \mathrm{ha}^{-1}$ yield was harvested from "CIP-118" and "CIP-218" at both conditions with a reduction of $11.41 \%$ and $7.45 \%$, respectively. In our study, marketable yield $\left(\mathrm{kg} \mathrm{plot}^{-1}\right)$ at $90 \mathrm{~d}$ of sixteen potato genotypes varied significantly under both non-stress and stress planted conditions (Table 7). It was found that the stress planting condition reduced average marketable yield $21.78 \%$ at $90 \mathrm{~d}$ harvest while the non-marketable yield $\left(\mathrm{kg} \mathrm{plot}^{-1}\right)$ did not vary significantly; however, in the stress planted 
condition it was found to be $200 \%$ more. In the present study, this proves that heat stress affects the total and marketable yield of potatoes by reducing the number and weight of tubers and also causing tuber disorders. Thus far, a relatively small number of heat-tolerant potato cultivars are recognized.

Table 6. Tuber yield ( $\mathrm{t} \mathrm{ha}^{-1}$ ) at 70 and 90 DAP of 16 potato genotypes under non-stress and heat stress conditions.

\begin{tabular}{|c|c|c|c|c|c|c|}
\hline \multirow{2}{*}{ Clones/Varieties } & \multicolumn{2}{|c|}{ Yield at 70 DAP (t ha ${ }^{-1}$ ) } & \multirow{2}{*}{$\begin{array}{c}\% \text { Yield } \\
\text { Reduction over } \\
\text { Non-Stress }\end{array}$} & \multicolumn{2}{|c|}{ Yield at 90 DAP (t ha ${ }^{-1}$ ) } & \multirow{2}{*}{$\begin{array}{c}\% \text { Yield } \\
\text { Reduction over } \\
\text { Non-Stress }\end{array}$} \\
\hline & Non-Stress & Heat Stress & & Non-Stress & Heat Stress & \\
\hline CIP-112 & 24.71 & 23.30 & 5.71 & 32.42 bcde & $21.13 \mathrm{de}$ & 34.82 \\
\hline CIP-118 & 30.96 & 26.43 & 14.63 & $34.17 \mathrm{abcd}$ & 30.27 cde & \\
\hline CIP-127 & 20.92 & 20.44 & 2.29 & $38.48 \mathrm{ab}$ & $32.22 \mathrm{ab}$ & 16.27 \\
\hline CIP-139 & 27.77 & 23.44 & 15.59 & $35.15 \mathrm{abcd}$ & 26.92 abcde & 23.41 \\
\hline CIP-202 & 21.36 & 20.00 & 6.37 & 32.47 bcde & 24.75 bcde & 23.78 \\
\hline CIP-203 & 29.24 & 27.58 & 5.68 & 33.38 abcd & 22.89 cde & 31.43 \\
\hline CIP-205 & 21.14 & 18.83 & 10.93 & $40.66 \mathrm{a}$ & $29.95 \mathrm{abc}$ & 26.34 \\
\hline CIP-218 & 32.47 & 30.05 & 7.45 & $25.32 \mathrm{e}$ & $20.39 \mathrm{e}$ & 19.47 \\
\hline CIP-220 & 22.60 & 19.30 & 14.60 & $38.12 \mathrm{abc}$ & $32.89 \mathrm{a}$ & 13.72 \\
\hline CIP-221 & 24.53 & 23.41 & 4.57 & 33.25 abcd & $21.78 \mathrm{de}$ & 34.50 \\
\hline CIP-229 & 28.53 & 21.02 & 26.32 & 27.99 de & 26.74 abcde & 4.47 \\
\hline CIP-232 & 26.92 & 22.41 & 16.75 & $32.84 \mathrm{bcd}$ & 24.78 bcde & 24.54 \\
\hline CIP-235 & 26.14 & 24.80 & 5.13 & 30.89 cde & $22.32 \mathrm{de}$ & 27.74 \\
\hline Granola & 23.72 & 21.91 & 7.63 & $29.90 \mathrm{de}$ & 26.90 abcde & 10.03 \\
\hline LB-7 & 25.43 & 24.78 & 2.56 & $28.37 \mathrm{de}$ & 24.13 cde & 14.95 \\
\hline Asterix & 20.97 & 19.01 & 9.35 & $34.24 \mathrm{abcd}$ & $28.56 \mathrm{abcd}$ & 16.59 \\
\hline Mean $\pm S D$ & $25.66 \pm 4.04$ & $23.16 \pm 3.63$ & & $32.78 \pm 4.04$ & $25.80 \pm 3.77$ & \\
\hline Range & $20.92-34.17$ & $18.83-30.27$ & & & & \\
\hline
\end{tabular}

Means with the same letter are not significantly different.

Table 7. Average of marketable and non-marketable tuber yield $\left(\mathrm{kg} \mathrm{plot}^{-1}\right)$ at 90 DAP of 16 potato genotypes under non-stress and heat stress conditions.

\begin{tabular}{ccccc}
\hline \multirow{2}{*}{ Clones/Varieties } & \multicolumn{2}{c}{ Marketable Yield $\left.\mathbf{( k g ~ p l o t} \mathbf{~}^{-1}\right)$} & \multicolumn{2}{c}{ Non-Marketable Yield $\mathbf{~ ( k g ~ p l o t ~}^{-\mathbf{1})}$} \\
\cline { 2 - 5 } & Non-Stress & Heat Stress & Non-Stress & Heat Stress \\
\hline CIP-112 & $11.08 \mathrm{cde}$ & $9.32 \mathrm{abcd}$ & 0.060 & 0.196 \\
CIP-118 & $13.82 \mathrm{ab}$ & $11.53 \mathrm{a}$ & 0.033 & 0.073 \\
CIP-127 & $12.62 \mathrm{abcd}$ & $9.54 \mathrm{abcd}$ & 0.040 & 0.150 \\
CIP-139 & $11.65 \mathrm{bcde}$ & $8.83 \mathrm{bcd}$ & 0.040 & 0.086 \\
CIP-202 & $11.99 \mathrm{abcd}$ & $8.13 \mathrm{bcd}$ & 0.020 & 0.106 \\
CIP-203 & $14.59 \mathrm{a}$ & $10.69 \mathrm{ab}$ & 0.050 & 0.090 \\
CIP-205 & $9.07 \mathrm{e}$ & $7.16 \mathrm{~d}$ & 0.043 & 0.156 \\
CIP-218 & $13.66 \mathrm{abc}$ & $11.68 \mathrm{a}$ & 0.053 & 0.123 \\
CIP-220 & $11.93 \mathrm{abcd}$ & $7.72 \mathrm{~cd}$ & 0.043 & 0.160 \\
CIP-221 & $10.03 \mathrm{de}$ & $9.47 \mathrm{abcd}$ & 0.046 & 0.126 \\
CIP-229 & $11.76 \mathrm{bcd}$ & $8.79 \mathrm{bcd}$ & 0.063 & 0.053 \\
CIP-232 & $11.09 \mathrm{cde}$ & $7.98 \mathrm{~cd}$ & 0.023 & 0.123 \\
CIP-235 & $10.73 \mathrm{de}$ & $9.56 \mathrm{abcd}$ & 0.033 & 0.073 \\
Granola & $10.19 \mathrm{de}$ & $8.61 \mathrm{bcd}$ & 0.020 & 0.120 \\
LB-7 & $12.28 \mathrm{abcd}$ & $10.16 \mathrm{abc}$ & 0.046 & 0.060 \\
Asterix & $11.64 \mathrm{bcde}$ & $7.55 \mathrm{~cd}$ & 0.037 & $0.12 \pm 0.04$ \\
Mean \pm SD & $11.76 \pm 1.45$ & $9.17 \pm 1.35$ & $0.04 \pm 0.01$ & $0.053-0.196$ \\
Range & $9.07-14.59$ & $7.16-11.53$ & $0.020-0.060$ & \\
\hline
\end{tabular}

Means with the same letter are not significantly different.

The most heat-vulnerable stages of potato growth and development are tuber initiation and tuber bulking. The tuber initiation stage starts with inhibition of the longitudinal growth of the stolons and swelling of the first internode behind the stolon apical bud to form initial tuber. In this study, under heat stress conditions, tuber initiation followed by tuber bulking started around $1.67 \mathrm{~d}$ earlier. However, in control/non-stress conditions, the increase in the weight and size of the tubers occurred in an almost linear fashion and turned into the main site for the deposition of starch and other nutrients. However, the source-sink relationships between foliage and tubers were affected by heat stress 
and also enhanced stem growth and branching, increased the leaf number but caused a reduction in leaf size and total leaf area [32]. Our research showed that heat stress harshly lowers the tuber development and tuber weight by interrupting the tuberization signal (30), changing the expression of the genes related to the circadian clock [30] as well as reducing an accumulation of carbon into starch in the tuber [30] and the fact remains that plants under heat stress remained largely green until harvest (data not shown). The findings of the current study are in line with earlier comparable findings [31,33]. In mild heat stress $\left(30 / 20{ }^{\circ} \mathrm{C}\right.$ day /night, 5 weeks) conditions, potato plants displayed a change in assimilate partitioning indicated by the greatly increased leaf dry matter and reduced tuber fresh and dry weight, dry matter and harvest index [30]. Recent breakthroughs have revealed that elevated temperature probably hinders tuber initiation by suppressing the expression of tuberization signal protein, named StSP6A [30]. At a mildly elevated temperature regime $\left(30 / 20{ }^{\circ} \mathrm{C}\right.$, day/night), StSP6A transcript levels in leaves decreased by up to $50 \%$ at most time points during the 24-h cycle [30].

\subsection{Comparing Genotypes Based on the Resistance/Tolerance Indices}

To explore suitable stress resistance indices for the screening of genotypes under heat stress conditions, average tuber yield per plant of potato genotypes under both non-stress (control) and stress conditions (late planting) were measured for calculating different sensitivity and tolerance indices (Table 8). Genotypes with high yield under stress conditions (Ys), "CIP-218" ranked first followed by "CIP-118", "CIP-203", "LB-7" and "CIP-221", while in non-stress conditions "CIP-203" ranked first, followed by "CIP-118", "CIP-218", "CIP-127" and "LB-7". The genotype "CIP-221" had the highest yield stability index (YSI) with the lowest stress susceptibility index followed by "CIP-232", "CIP-218" and "CIP-112". A yield reduction ratio (YR) with a low value would be more tolerant to stress and this followed a similar trend to the stress susceptibility index (SSI).

According to Abiotic stress tolerance index (ASTI), MP and GMP values, the five genotypes namely "CIP-218", “CIP-203", "CIP-118", "CIP-LB-7" and "CIP-127" were identified as heat-tolerant genotypes. While genotypes such as "CIP-205", "Asterix" and "CIP232" were identified as susceptible genotypes, because of their low values for ASTI, MP and GMP. Genotypes with low tolerance (TOL) will be more tolerant to heat stress and "CIP-221" showed the lowest value followed by "CIP-232", "Granola", "CIP-112" and "CIP-218". Calculation of stress resistance index (SRI) yield index (YI) and relative stress index (RSI) showed that the highest index value was related to the four genotypes namely "CIP-218", "CIP-221", "LB-7", "CIP-118" and "CIP-232", indicating that these genotypes had lower per plant tuber yield reduction under stress conditions and the highest sensitivity to heat stress conditions. Among all genotypes, "CIP-220", "Asterix" and "CIP-202" with high SSI were identified as heat susceptible genotypes and suited for the non-stress condition. It seems that indices TOL and SSI had succeeded in the selection of genotypes with high yield under stress conditions but had failed to select genotypes with proper yield under both environments. Finally, the abiotic tolerance index (ATI) was also used and the genotypes with low values of the parameter can be selected as tolerant genotypes to heat stress. In this study, genotypes such as "CIP-221", "CIP-232", "CIP-218", "Granola" and "CIP-112" were identified as heat-tolerant genotypes. 
Table 8. Mean tuber yield plant ${ }^{-1}(\mathrm{~kg})$ under non-stress and late planting conditions and measures of different screening methods for 16 potato genotypes.

\begin{tabular}{|c|c|c|c|c|c|c|c|c|c|c|c|c|c|}
\hline \multirow{3}{*}{ Genotype } & \multicolumn{2}{|c|}{ Yield Plant $^{-1}$ (kg) } & \multicolumn{11}{|c|}{ Stress Indices } \\
\hline & Ys & Yp & YSI & SSI & YRR & MP & GMP & TOL & HTI & SRI & ASTI & YI & RHI \\
\hline & 1 & 2 & 3 & 4 & 5 & 6 & 7 & 8 & 9 & 10 & 11 & 12 & 13 \\
\hline Asterix & 0.32 & 0.49 & 0.65 & 1.64 & 0.35 & 0.41 & 0.40 & 0.17 & 0.65 & 0.43 & 0.085 & 0.83 & 0.83 \\
\hline CIP-112 & 0.39 & 0.46 & 0.85 & 0.72 & 0.15 & 0.43 & 0.42 & 0.07 & 0.74 & 0.67 & 0.038 & 1.01 & 1.08 \\
\hline CIP-118 & 0.48 & 0.57 & 0.84 & 0.75 & 0.16 & 0.53 & 0.52 & 0.09 & 1.13 & 0.82 & 0.060 & 1.24 & 1.07 \\
\hline CIP-127 & 0.40 & 0.53 & 0.75 & 1.16 & 0.25 & 0.47 & 0.46 & 0.13 & 0.88 & 0.62 & 0.076 & 1.04 & 0.96 \\
\hline CIP-139 & 0.37 & 0.48 & 0.77 & 1.08 & 0.23 & 0.43 & 0.42 & 0.11 & 0.74 & 0.58 & 0.059 & 0.96 & 0.98 \\
\hline CIP-202 & 0.34 & 0.50 & 0.68 & 1.51 & 0.32 & 0.42 & 0.41 & 0.16 & 0.70 & 0.47 & 0.084 & 0.88 & 0.86 \\
\hline CIP-203 & 0.45 & 0.61 & 0.74 & 1.24 & 0.26 & 0.53 & 0.52 & 0.16 & 1.14 & 0.68 & 0.106 & 1.17 & 0.94 \\
\hline CIP-205 & 0.30 & 0.38 & 0.79 & 0.99 & 0.21 & 0.34 & 0.34 & 0.08 & 0.47 & 0.48 & 0.034 & 0.78 & 1.00 \\
\hline CIP-218 & 0.49 & 0.57 & 0.86 & 0.66 & 0.14 & 0.53 & 0.53 & 0.08 & 1.16 & 0.86 & 0.054 & 1.27 & 1.09 \\
\hline CIP-220 & 0.32 & 0.50 & 0.64 & 1.70 & 0.36 & 0.41 & 0.40 & 0.18 & 0.66 & 0.42 & 0.091 & 0.83 & 0.81 \\
\hline CIP-221 & 0.41 & 0.42 & 0.98 & 0.11 & 0.02 & 0.42 & 0.41 & 0.01 & 0.71 & 0.82 & 0.005 & 1.06 & 1.24 \\
\hline CIP-229 & 0.37 & 0.49 & 0.76 & 1.16 & 0.24 & 0.43 & 0.43 & 0.12 & 0.75 & 0.57 & 0.065 & 0.96 & 0.96 \\
\hline CIP-232 & 0.34 & 0.46 & 0.74 & 1.23 & 0.26 & 0.40 & 0.40 & 0.12 & 0.65 & 0.51 & 0.060 & 0.88 & 0.94 \\
\hline CIP-235 & 0.40 & 0.45 & 0.89 & 0.52 & 0.11 & 0.43 & 0.42 & 0.05 & 0.75 & 0.73 & 0.027 & 1.04 & 1.13 \\
\hline Granola & 0.37 & 0.44 & 0.84 & 0.75 & 0.16 & 0.41 & 0.40 & 0.07 & 0.67 & 0.63 & 0.036 & 0.96 & 1.07 \\
\hline LB-7 & 0.43 & 0.51 & 0.84 & 0.74 & 0.16 & 0.47 & 0.47 & 0.08 & 0.91 & 0.74 & 0.048 & 1.11 & 1.07 \\
\hline
\end{tabular}

YSI, Yield stability index; SSI, Stress susceptibility index; YRR, Yield reduction ratio; MP, Mean productivity; GMP, Geometric mean productivity; TOL, Tolerance; HTI, Stress tolerance index; SRI, Stress resistance index; ASTI, Abiotic stress tolerance index; YI, Yield index; RHI, Relative stress index.

\subsection{Ranking of the Genotypes}

The estimates of an indicator of stress tolerance (Tables 8 and 9) revealed that the detection of heat-tolerant genotypes was ambiguous based on a single criterion. Different indices introduced different genotypes as heat tolerant. The following ranking method was used to give a comprehensive assessment. To determine the most desirable heat tolerant genotype according to all indices, mean rank, the standard deviation of the ranks and rank-sum (RS) of all heat tolerance criteria were computed and based on these criteria. The most desirable heat/stress-tolerant genotypes were identified in consideration of all indices, "CIP-218", exhibited the lowest RS followed by four genotypes namely, "LB-7", "CIP-118", "CIP-232" and "CIP-112", while the genotypes "CIP-220" and "Asterix" were identified as the most heat-sensitive (Table 9). Another control variety "Granola" had a moderate sensitivity to heat stress. Therefore, these genotypes are recommended to be used as parents for genetic analysis and improvement of heat tolerance in potatoes. The ranking method has been used for screening drought/stress-tolerant cultivars by Khalili et al. [34] in canola, Farshadfar and Elyasi [20]; Farshadfar et al. [35]; Ashraf et al. [36] in bread wheat; Mahmud et al. [37] and Mahmud et al. [38] in potato.

Table 9. Rank, rank mean (RM), standard deviation of ranks (SDR) and rank sum (RS) of stress resistance/tolerance indices.

\begin{tabular}{|c|c|c|c|c|c|c|c|c|c|c|c|c|c|c|c|c|c|}
\hline \multirow{3}{*}{ Genotype } & \multicolumn{2}{|c|}{ Yield Plant ${ }^{-1}$ (kg) } & \multicolumn{11}{|c|}{ Stress Indices } & \multirow{2}{*}{$\mathbf{R M}$} & \multirow{2}{*}{ SDR } & \multirow{2}{*}{ RS } & \multirow{2}{*}{ Rank } \\
\hline & Ys & $Y p$ & YSI & SSI & YRR & MP & GMP & TOL & HTI & SRI & ASTI & YI & RHI & & & & \\
\hline & 1 & 2 & 3 & 4 & 5 & 6 & 7 & 8 & 9 & 10 & 11 & 12 & 13 & 14 & 15 & 16 & 17 \\
\hline Asterix & 14.5 & 8.0 & 15.0 & 15.0 & 16.0 & 13.0 & 15.0 & 16.0 & 14.0 & 15.0 & 13.0 & 14.5 & 15.0 & 14.2 & 2.1 & 16.2 & 15 \\
\hline CIP-112 & 8.0 & 11.5 & 4.0 & 4.0 & 4.0 & 7.5 & 8.0 & 3.5 & 8.0 & 7.0 & 5.0 & 8.0 & 4.0 & 6.3 & 2.4 & 8.8 & 5 \\
\hline CIP-118 & 2.0 & 2.0 & 5.0 & 6.0 & 6.0 & 3.0 & 3.0 & 8.0 & 3.0 & 2.0 & 9.5 & 2.0 & 6.0 & 4.4 & 2.5 & 6.9 & 3 \\
\hline CIP-127 & 6.5 & 4.0 & 11.0 & 11.0 & 11.0 & 4.5 & 5.0 & 12.0 & 5.0 & 9.0 & 12.0 & 6.5 & 11.0 & 8.3 & 3.1 & 11.5 & 9 \\
\hline CIP-139 & 10.5 & 10.0 & 9.0 & 9.0 & 9.0 & 7.5 & 9.0 & 9.0 & 9.0 & 10.0 & 8.0 & 10.0 & 9.0 & 9.2 & 0.8 & 10.0 & 7 \\
\hline CIP-202 & 12.5 & 6.5 & 14.0 & 14.0 & 14.0 & 10.5 & 11.0 & 13.0 & 11.0 & 14.0 & 14.0 & 13.0 & 14.0 & 12.4 & 2.2 & 14.6 & 13 \\
\hline CIP-203 & 3.0 & 1.0 & 13.0 & 13.0 & 13.0 & 1.5 & 2.0 & 14.0 & 2.0 & 6.0 & 16.0 & 3.0 & 13.0 & 7.7 & 5.9 & 13.6 & 11 \\
\hline CIP-205 & 16.0 & 16.0 & 8.0 & 8.0 & 8.0 & 16.0 & 16.0 & 5.5 & 16.0 & 13.0 & 3.0 & 16.0 & 8.0 & 11.5 & 4.8 & 16.3 & 14 \\
\hline CIP-218 & 1.0 & 3.0 & 3.0 & 3.0 & 3.0 & 1.5 & 1.0 & 5.5 & 1.0 & 1.0 & 7.0 & 1.0 & 3.0 & 2.6 & 1.9 & 4.5 & 1 \\
\hline CIP-220 & 14.5 & 6.5 & 16.0 & 16.0 & 15.0 & 13.0 & 14.0 & 15.0 & 13.0 & 16.0 & 15.0 & 14.5 & 16.0 & 14.2 & 2.5 & 16.7 & 16 \\
\hline CIP-221 & 5.0 & 15.0 & 1.0 & 1.0 & 1.0 & 10.5 & 10.0 & 1.0 & 10.0 & 3.0 & 1.0 & 5.0 & 1.0 & 5.0 & 4.8 & 9.8 & 6 \\
\hline CIP-229 & 10.5 & 9.0 & 10.0 & 10.0 & 10.0 & 7.5 & 6.0 & 10.5 & 6.0 & 11.0 & 11.0 & 10.0 & 10.0 & 9.3 & 1.7 & 11.1 & 8 \\
\hline CIP-232 & 12.5 & 11.5 & 12.0 & 12.0 & 12.0 & 15.0 & 15.0 & 10.5 & 15.0 & 12.0 & 9.5 & 12.0 & 12.0 & 12.4 & 1.7 & 14.1 & 12 \\
\hline CIP-235 & 6.5 & 13.0 & 2.0 & 2.0 & 2.0 & 7.5 & 7.0 & 2.0 & 7.0 & 5.0 & 2.0 & 6.5 & 2.0 & 5.0 & 3.4 & 8.3 & 4 \\
\hline Granola & 9.0 & 14.0 & 7.0 & 7.0 & 6.0 & 13.0 & 13.0 & 3.5 & 12.0 & 8.0 & 4.0 & 10.0 & 7.0 & 8.7 & 3.5 & 12.2 & 10 \\
\hline LB-7 & 4.0 & 5.0 & 6.0 & 5.0 & 6.0 & 4.5 & 4.0 & 7.0 & 4.0 & 4.0 & 6.0 & 4.0 & 5.0 & 5.0 & 1.0 & 6.0 & 2 \\
\hline
\end{tabular}

YSI, Yield stability index; SSI, Stress susceptibility index; YRR, Yield reduction ratio; MP, Mean productivity; GMP, Geometric mean productivity; TOL, Tolerance; HTI, Stress tolerance index; SRI, Stress resistance index; ASTI, Abiotic stress tolerance index; YI, Yield index; RHI, Relative stress index; RM, rank mean; SDR, standard deviation of ranks; RS, rank sum. 


\section{Conclusions}

In this study, it was found that heat stress increased plant height, stem per plant, canopy coverage, plant vigor and tuber number per plant of potato. However, it reduced the tuber yield by reducing the average tuber weight per plant. In this evaluation, selection of heat-tolerant potato genotypes with desirable yield in both stress and non-stress conditions was done based on several indices rather than only one index's information. Last but not least, the multiple statistical procedures which were used in this study showed that, among all the genotypes, "CIP-218", "LB-7", "CIP-118", "CIP-232" and "CIP-112" were identified as the heat-tolerant potato genotypes and it may be recommended to release a variety(s) for commercial cultivation in heat prone areas of South-Asia including Bangladesh.

Author Contributions: Conceptualization, A.A.M., M.J.A. and E.H.M.S.R.; methodology, A.A.M., M.J.A. and B.C.K.; software, M.M.R.; validation, A.A.M., M.J.A., B.C.K., M.S. (Mousumi Sultana) and M.S.H.M.; formal analysis, A.A.M., M.J.A., A.H., A.M.E.-S. and A.E.S.; investigation, A.A.M., M.J.A., M.S.H.M. and B.C.K.; resources, A.A.M.; data curation, A.A.M., M.J.A. and A.H.; writing-original draft preparation, A.A.M., M.J.A. and M.S.H.M.; writing—review and editing, M.S. (Milan Skalicky), M.B., A.H., E.H.M.S.R., A.M.E.-S., and A.E.S.; visualization, A.A.M., M.J.A., M.S.H.M. and B.C.K.; supervision, A.A.M.; project administration, A.A.M.; funding acquisition, M.S. (Milan Skalicky), M.B., A.H., E.H.M.S.R., A.M.E.-S., and A.E.S. All authors have read and agreed to the published version of the manuscript.

Funding: The current work was funded by Taif University Researchers Supporting Project number (TURSP-2020/75), Taif University, Taif, Saudi Arabia.

Institutional Review Board Statement: Not applicable.

Informed Consent Statement: Not applicable.

Data Availability Statement: Data may be available after requesting to corresponding author.

Acknowledgments: We earnestly give thanks to the Director-General of Bangladesh Agricultural Research Institute (BARI) for delivering the services for this study and we are thankful to the International Potato Center (CIP), USAID Horticulture Project, Bangladesh authority for awarding research expenses. The authors extend their appreciation to Taif University for funding the current work by Taif University Researchers Supporting Project number (TURSP-2020/75), Taif University, Taif, Saudi Arabia.

Conflicts of Interest: The authors declare no conflict of interest. The funders had no role in the design of the study; in the collection, analyses, or interpretation of data; in the writing of the manuscript, or in the decision to publish the results.

\section{References}

1. FAOSTAT. 2017. Available online: http:/ / www.fao.org/faostat/en/\#data/QC (accessed on 6 June 2018).

2. Scott, G.J.; Rosegrant, M.W.; Ringler, C. Global projections for root and tuber crops to the year 2020. Food Policy 2000, $25,561-597$. [CrossRef]

3. Thiele, G.; Theisen, K.; Bonierbale, M.; Walker, T. Targeting the poor and hungry with potato science. Potato J. $2010,37,75-86$.

4. Badoni, A.; Chauhan, J.S. Importance of Potato Micro Tuber Seed Material for Farmers of Uttarakhand Hills. Int. J. Sustain. Agric. 2010, 2, 1-9.

5. Walker, T.; Thiele, G.; Suarez, V.; Crissman, C. Hindsight and Foresight about Potato Production and Consumption; Social Sciences Working Paper 2011-5; International Potato Centre (CIP): Lima, Peru, 2011; 43p.

6. Scott, G.; Suarez, V. From Mao to McDonald's: Emerging markets for potatoes and potato products in China 1961-2007. Am. J. Potato Res. 2012, 89, 216-231. [CrossRef]

7. FAOSTAT. Production Yearbook; Food and Agriculture Organization of the United Nations: Rome, Italy, 2018.

8. Burton, W.G. Challenges for stress physiology in potato. Am. Potato J. 1981, 58, 3-14. [CrossRef]

9. Levy, D.; Veilleux, R.E. Adaptation of potato to high temperatures and salinity-A review. Am. J. Potato Res. 2007, 84, 487-506. [CrossRef]

10. van Oort, P.A.J.; Saito, K.; Zwart, S.J.; Shrestha, S. A simple model for simulating heat-induced sterility in rice as a function of flowering time and transpirational cooling. Field Crop. Res. 2014, 156, 303-312. [CrossRef]

11. Tang, R.; Niu, S.; Zhang, G.; Chen, G.; Haroon, M.; Yang, Q.; Rajora, O.P.; Li, X.-Q. Physiological and growth responses of potato cultivars to heat stress. Botany 2018, 96, 897-912. [CrossRef] 
12. Hijmans, R.J. The effect of climate change on global potato production. Am. J. Potato Res. 2003, 80, 271-279. [CrossRef]

13. Sharma, S.; Upadhyaya, H.D.; Varshney, R.K.; Gowda, C.L.L. Pre-breeding for diversification of primary gene pool and genetic enhancement of grain legumes. Front. Plant Sci. 2013, 4, 309. [CrossRef] [PubMed]

14. Minhas, J.S.; Rawat, S.; Govindakrishnan, P.M.; Kumar, D. Possibilities in enhancing potato production in non-traditional areas. Potato J. 2011, 38, 14-17.

15. Sunitha, S.; Gupta, V.K.; Anil, S.R.; Kumar, J.S. Performance of Heat Tolerant Clones of Potato in Tropical Coastal Region of India. Int. J. Curr. Microbiol. Appl. Sci. 2020, 9, 2961-2967. [CrossRef]

16. Monneveux, P.; Ramírez, D.A.; Khan, M.A.; Raymundo, R.M.; Loayza, H.; Quiroz, R. Drought and Heat Tolerance Evaluation in Potato (Solanum tuberosum L.). Potato Res. 2014, 57, 225-247. [CrossRef]

17. Quiroz, R.; Ramírez David, A.; Kroschel, J.; Andrade-Piedra, J.; Barreda, C.; Condori, B.; Mares, V.; Monneveux, P.; Perez, W. Impact of climate change on the potato crop and biodiversity in its center of origin. Open Agric. 2018, 3, 273-283. [CrossRef]

18. Singh, B.; Kukreja, S.; Goutam, U. Impact of heat stress on potato (Solanum tuberosum L.): Present scenario and future opportunities. J. Hortic. Sci. Biotechnol. 2020, 95, 407-424. [CrossRef]

19. BARC (Bangladesh Agricultural Research Council). Fertilizer Recommendation Guide; BARC: Farmgate, Dhaka, $2012 ;$ pp. 29-30.

20. Farshadfar, E.; Elyasi, P. Screening quantitative indictors of drought tolerance in bread wheat (Triticum aestivum L.) landraces. Eur. J. Exp. Biol. 2012, 2, 577-584.

21. Bouslama, M.; Schapaugh, W.T. Stress Tolerance in Soybean. Part 1: Evaluation of Three Screening Techniques for Heat and Drought Tolerance. Crop Sci. 1984, 24, 933-937. [CrossRef]

22. Fischer, R.; Maurer, R. Drought Resistance in Spring Wheat Cultivars. I. Grain Yield Responses. Aust. J. Agric. Res. 1978, 29, 897-912. [CrossRef]

23. Golestani Araghi, S.; Assad, M.T. Evaluation of four screening techniques for drought resistance and their relationship to yield reduction ratio in wheat. Euphytica 1998, 103, 293-299. [CrossRef]

24. Rosielle, A.A.; Hamblin, J. Theoretical aspects of selection for yield in stress and nonstress environments. Crop Sci. 1981, 21, 943-946. [CrossRef]

25. Kristin, A.S.; Senra, R.R.; Perez, F.I.; Enriquez, B.C.; Gallegos, J.A.A.; Vallego, P.R.; Wassimi, N.; Kelley, J.D. Improving common bean performance under drought stress. Crop Sci. 1997, 37, 43-50.

26. Fernandez, G.C.J. Effective selection criteria for assessing plant stress tolerance. In Adaptation of Food Crops to Temperature and Water Stress; Kuo, C.G., Ed.; Asian Vegetable Research and Development Center (AVRDC): Tainan, Taiwan, 1992; Volume 93, p. 257.

27. Lan, J. Comparison of evaluating methods for agronomic drought resistance in crops. Acta Agric. Borealioccidentalis Sin. 1998, 7 , 85-87.

28. Moosavi, S.S.; Yazdi-Samadi, B.; Naghavi, M.R.; Zali, A.A.; Dashti, H.; Pourshahbazi, A. Introduction of new indices to identify relative drought tolerance and resistance in wheat genotypes. Desert 2008, 12, 165-178.

29. Gavuzzi, P.; Rizza, F.; Palumbo, M.; Campaline, R.G.; Ricciardi, G.L.; Borghi, B. Evaluation of field and laboratory predictors of drought and heat tolerance in winter cereals. Can. J. Plant Sci. 1997, 77, 523-531. [CrossRef]

30. Hancock, R.D.; Morris, W.L.; Ducreux, L.J.M.; Morris, J.A.; Usman, M.; Verrall, S.R.; Fuller, J.; Simpson, C.G.; Zhang, R.; Hedley, P.E.; et al. Physiological, biochemical and molecular responses of the potato (Solanum tuberosum L.) plant to moderately elevated temperature. Plant Cell Environ. 2014, 37, 439-450. [CrossRef] [PubMed]

31. Paul, S.; Bose, I.; Gogoi, N. Morphophysiological responses: Criteria for screening heat tolerance in potato. Curr. Sci. 2016, 111, 1226-1231. [CrossRef]

32. Struik, P.C. Responses of the potato plant to temperature. In Potato Biology and Biotechnology: Advances and Perspectives; Vreugdenhil, D., Ed.; Elsevier: Oxford, UK; Amsterdam, The Netherlands, 2007; pp. 367-393.

33. Demirel, U.; Çalişkan, S.; Yavuz, C.; Tindaş, İ.; Polgar, Z.; Vaszily, Z.; Cernák, I.; Çalişkan, M.E. Assessment of morphophysiological traits for selection of heat-tolerant potato genotypes. Turk. J. Agric. For. 2017, 41, 218-232. [CrossRef]

34. Khalili, M.; Naghavi, M.R.; Pour Aboughadareh, A.R.; Talebzadeh, J. Evaluating of Drought Stress Tolerance based on selection indices in spring canola cultivars (Brassica napus L.). J. Agric. Sci. 2012, 4, 78-85. [CrossRef]

35. Farshadfar, E.; Farshadfar, M.; Dabiri, S. Comparison between effective selection criteria of drought tolerance in bred wheat landraces in Iran. Ann. Biol. Res. 2012, 3, 3381-3389.

36. Ashraf, A.; El-Mohsen, A.; Abd El-Shafi, M.A.; Gheith, E.M.S.; Suleiman, H.S. Using different statistical procedures for evaluating drought tolerance indices of bread wheat genotypes. Adv. Agric. Biol. 2015, 4, 19-30.

37. Mahmud, A.A.; Hossain, M.; Bazzaz, M.M.; Khan, M.S.A.; Hossain, M.A.; Kadian, M.S. Tuber Yield, Tuber Quality and Plant Water Status of Potato under Drought and Well-Watered Condition. Glob. J. Sci. Front. Res. 2014, 14, $101-107$.

38. Mahmud, A.A.; Hossain, M.; Zakaria, M.; Mian, M.A.K.; Karim, M.A.; Hossain, M. Stress tolerance attributes and yield based selection of potato genotypes for water stress environment. Songklanakarin J. Sci. Technol. 2017, 39, $185-194$. 